\title{
Developing Ecological Indicators of Visitor use of Protected Areas: A New Integrated Framework from Australia
}

\author{
J. Guy Castley ${ }^{1,2, *}$, Wendy Hill², Catherine M. Pickering ${ }^{2}$ \\ ${ }^{1}$ Environmental Futures Centre, ${ }^{2}$ International Centre for Ecotourism Research \\ Griffith School of Environment, Gold Coast campus, Griffith University, Queensland 4222 \\ * corresponding author: g.castley@griffith.edu.au, (07) 55527784
}

\begin{abstract}
Sustainable tourism is considered an appropriate use of many Australian protected areas. However, such use needs to be managed, and the effectiveness of management needs to be assessed as over-use can adversely affect the natural environment. Monitoring and management of visitor impacts requires integration into evaluation frameworks to enable more efficient reporting but within Australia this appears to be poorly developed. We have developed a framework that integrates visitor impact monitoring and evaluation within adaptive management cycles to improve management responses. The framework uses existing management processes, where possible, for focusing monitoring efforts and selecting appropriate ecological indicators. This focus is achieved through a process of prioritisation of natural assets used by visitors, or those likely to be impacted by visitor use. The framework follows a sequential, adaptive cycle of identifying natural asset values, their vulnerability, and use by visitors to derive appropriate indicators for monitoring. The indicators selected using the framework are linked to existing evaluation frameworks to provide baseline information for core protected area evaluation across a variety of spatial scales. We outline the functionality of the framework using a six step process and expand on the ability of the framework to be applied in other protected area management situations.
\end{abstract}

Keywords sustainable tourism, evaluation, adaptive management, monitoring 


\section{Introduction}

Setting aside protected areas (PA) is one of the main strategies by which countries fulfil their national and international obligations to conserve biodiversity (Margules \& Pressey 2000; Worboys et al. 2005), although not all PA categories are likely to achieve biodiversity conservation objectives (Locke \& Dearden 2005). In Australia, over 7720 protected areas, as defined by the World Commission on Protected Areas (WCPA), cover more than ten per cent of the land (DEH 2006; Table 1). Furthermore, there are at least 50 categories of reserve types from specific-purpose areas to very large, multi-zoned areas (Worboys et al. 2005).

Table 1 Extent of Australian terrestrial protected areas categorized by IUCN-World Conservation Union Protected area management categories (DEH 2006).

\begin{tabular}{llll}
\hline \hline WCPA & Purpose & Number & Area (ha) \\
Category & & & \\
\hline IA & Mainly for science & 2200 & 18515397 \\
IB & Mainly for wilderness protection & 44 & 4786179 \\
II & Mainly for ecosystem protection and recreation & 828 & 36148340 \\
III & Mainly for conservation of specific natural features & 2312 & 1104307 \\
IV & Mainly for conservation through management & 2149 & 2926137 \\
& intervention & & \\
V & Mainly for landscape/seascape conservation and & 203 & 850178 \\
VI & recreation & & \\
\hline Total & Mainly for sustainable use of natural ecosystems & 1044 & 25198320 \\
\hline \hline
\end{tabular}

Tourism is one of the world's fastest growing industries, and nature-based tourism is one of its largest components (Newsome et al. 2002a; UNEP-WCMC 2003). Increases in the demand for nature-based tourism and recreation are closely linked to supply, and in many cases this is provided by protected areas (Carey et al. 2000). The challenge is for protected areas to provide these services in a sustainable fashion. These global trends are replicated in Australia where much of the pressure for nature-based tourism and recreation is focused in and around protected areas, which received over 108 million visitors during 2004-2005 (Worboys 2007).

Visitor use of protected areas requires active management, as over-use or inappropriate use can cause adverse impacts. The ecological impacts of recreation activities in protected areas have been studied in Australia (Wilson et al. 2004; Turton 2005) and overseas (see Tables 2 and 3, and 
references therein). Some of the key threats associated with visitor use include disturbance to wildlife, introduction and spread of exotic species, pollution of water, soil erosion, damage to vegetation, and an increased risk of bushfires (Newsome et al. 2002a; Buckley 2004). In addition to these environmental consequences, over-use or inappropriate use also can reduce the quality of visitor experiences (Manning 1999; Leung \& Marion 2000; Choi \& Sirakaya 2006).

Understanding the impact of such use is critical for effective management, and visitor monitoring needs to be incorporated into general reporting mechanisms. This is of particular relevance considering the increasing pressure on protected area agencies to report on their management performance (Hockings et al. 2006).

Numerous frameworks, models, policies and plans have been developed to manage visitors and to minimise their ecological impacts (Brown et al. 2006). These usually propose monitoring of appropriate ecological indicators to provide information on changes in the condition of the environment. While the use of indicators (see Noss 1990,1999) may assist in the assessment of the status and trends in the condition of the environment, and may provide information that can be used to assess the extent to which management has been effective (Hockings et al. 2004, 2006), many authors continue to debate about what constitutes a good ecological indicator (e.g. Noss 1990; Buckley 2003; Niemi \& McDonald 2004). No single indicator is likely to satisfy all requirements, and an ideal set of indicators cannot be developed for implementation across a wide range of systems. Therefore, mechanisms and decision pathways to identify potential indicators are critical to ensuring the cost-effective implementation of monitoring efforts. 
Table 2: Summary of direct and indirect ecological impacts of visitor use on components of terrestrial ecosystems.

\begin{tabular}{|c|c|c|}
\hline Ecosystem component & Impact & Cause (visitor use) \\
\hline \multicolumn{3}{|l|}{ Soil } \\
\hline \multirow[t]{2}{*}{ Direct impact } & $\begin{array}{l}\text { Alteration to structure and composition } \\
\text { through compaction and loss of } \\
\text { organic litter }\end{array}$ & $\begin{array}{l}\text { Construction of infrastructure; camp fires; disposal of } \\
\text { human waste; burying rubbish }\end{array}$ \\
\hline & $\begin{array}{l}\text { Physical erosion of soils and parent } \\
\text { material }\end{array}$ & $\begin{array}{l}\text { Constant use of tracks impacts surrounding areas; } \\
\text { damage to vegetation allows water and wind to remove } \\
\text { soil; tracks redirect water flows }\end{array}$ \\
\hline Indirect impact & $\begin{array}{l}\text { Reduced soil moisture; reduced soil } \\
\text { pore space; reduced microbial activity }\end{array}$ & $\begin{array}{l}\text { Soil compaction with use; altered runoff patterns; } \\
\text { change in soil chemistry/moisture/airspaces }\end{array}$ \\
\hline \multicolumn{3}{|c|}{ Geological features (e.g. caves, lakes, hot pools, dunes, river margins, peri-glacial features, rock formations) } \\
\hline Direct impact & $\begin{array}{l}\text { Physical damage (e.g. breakage, } \\
\text { graffiti) }\end{array}$ & $\begin{array}{l}\text { High impact use (rock-climbing, mountain biking, horse- } \\
\text { riding, trail bikes) }\end{array}$ \\
\hline Indirect impact & $\begin{array}{l}\text { Reduced visual appeal; soil erosion \& } \\
\text { changes in hydrology in adjacent areas }\end{array}$ & $\begin{array}{l}\text { High impact use (rock-climbing, mountain-biking, } \\
\text { horse-riding, trail bikes) }\end{array}$ \\
\hline \multicolumn{3}{|l|}{ Landscape - general } \\
\hline Direct impact & $\begin{array}{l}\text { Alteration to vegetation structure; } \\
\text { alteration to land shape/landscape }\end{array}$ & $\begin{array}{l}\text { Camping; recreational trampling; off road vehicle use; } \\
\text { mountain bikes; snow mobiles; snow groomers; quad } \\
\text { bikes; collecting wood for fires; use of camp fires }\end{array}$ \\
\hline Indirect impact & Reduced visual appeal & $\begin{array}{l}\text { Camping; recreational trampling; off road vehicle use; } \\
\text { mountain bikes; snow mobiles; snow groomers; quad } \\
\text { bikes; collecting wood for fires; use of camp fires }\end{array}$ \\
\hline \multicolumn{3}{|l|}{ Wildlife } \\
\hline \multirow[t]{3}{*}{ Direct impact } & $\begin{array}{l}\text { Disruption of: activity; breeding } \\
\text { patterns; feeding /foraging; parental } \\
\text { behaviour; other behaviour }\end{array}$ & $\begin{array}{l}\text { Visitor behaviour (photography, light, sound); visitor use } \\
\text { intensity (crowding); light, sound, refuse and emissions } \\
\text { from adjacent areas where visitor facilities are } \\
\text { constructed }\end{array}$ \\
\hline & Disruption of habitat & $\begin{array}{l}\text { Physical disruption to vegetation and soils from } \\
\text { infrastructure, and activities; physical change from } \\
\text { introduction of weeds; disruption from feral animals; } \\
\text { supplemented food; inappropriate wildlife watching } \\
\text { behaviour e.g. boats manoeuvring too close to marine } \\
\text { wildlife. }\end{array}$ \\
\hline & Direct killing or injuring & Road accidents; hunting, fishing and collecting \\
\hline Indirect impact & $\begin{array}{l}\text { Reduced health; increased mortality; } \\
\text { reduced reproductive rates; change in } \\
\text { species composition of communities }\end{array}$ & Wildlife feeding; spotlighting, \\
\hline \multicolumn{3}{|l|}{ Vegetation } \\
\hline Direct impact & $\begin{array}{l}\text { Loss of ground cover; reduced: height, } \\
\text { growth, reproduction, biomass; loss of } \\
\text { species; tree trunk damage }\end{array}$ & $\begin{array}{l}\text { Camping; recreational trampling; off road vehicle use; } \\
\text { mountain bikes; snow mobiles; snow groomers; quad } \\
\text { bikes; collecting wood for fires; use of camp fires }\end{array}$ \\
\hline Indirect impact & $\begin{array}{l}\text { Introduction and spread of exotic } \\
\text { species; change in community species } \\
\text { composition; change in community age } \\
\text { structure; altered growth rates; altered } \\
\text { microclimate }\end{array}$ & $\begin{array}{l}\text { Introduction on visitor equipment and clothing; walking } \\
\text { off tracks }\end{array}$ \\
\hline
\end{tabular}

Sources: Buckley (2004); Cole (1985); Green \& Higginbottom (2001); Hadwen \& Arthington (2003); Hadwen et al. (2003); Hadwen \& Bunn (2004, 2005); Hadwen et al. (2005a, b); Hall \& McArthur (1993); Kuss et al. (1990); Leung \& Marion (2000); Liddle (1997); Newsome et al. (2002a,b; 2004); Sun \& Walsh (1998); Ward \& Beanland (1996). 
Table 3: Studies assessing the ecological impacts of specific recreation activities in Australian protected areas.

\begin{tabular}{ll}
\hline \hline Activity & Publication \\
\hline Hiking \& camping & Cole 2004. \\
$\begin{array}{l}\text { Mountain bike riding } \\
\text { Horse riding }\end{array}$ & Goeft and Alder 2001; Chiu and Kriwoken 2003 \\
Rock climbing & Candsberg et al. 2001; Newsome et al. 2002b, 2004, 2008, Smith and Newsome 2008 \\
Skiing and other snow & Pickering and Hill 2003. \\
based activities & \\
Rafting/kayaking & Hadwen et al. 2005b. \\
Driving (off road) & Buckley 2004; Lonsdale and Lane 1994; Buckley 2008. \\
Sailing/boating & Mosisch and Arthington 2004; Warnken and Byrnes 2004. \\
Fishing & Hadwen et al. 2005b. \\
Swimming & Butler et al. 1996; Hadwen and Arthington 2003; Hadwen et al. 2003; Hadwen and Bunn \\
\hline \hline
\end{tabular}

\section{Approach and framework development}

The international tourism, biodiversity and environmental management literature was reviewed to identify methods in use for monitoring visitor use in protected areas. Initially, visitor impacts and the use of indicators to monitor such impacts using a variety of existing performance evaluation methods were evaluated. This evaluation was used to develop an integrated framework that is based upon the lessons learned from previous research. The framework aims to prioritise visitor impact monitoring by encouraging managers to (i) identify critical park assets; (ii) review the vulnerability of such assets; and (iii) assess the pressure from visitors. In presenting the new framework, this article details the steps that are central in using the framework. We conclude with an example of how the new framework can be applied and suggest that this integrated framework can be implemented at various scales to meet the visitor management use requirements in protected areas, although it also has broader application to park management generally.

\section{Evaluating visitor impacts in protected areas}

Sustainable tourism within Australian protected areas is considered appropriate. However, visitor use needs to be managed and the effectiveness of management needs to be assessed as overuse or inappropriate use can degrade natural values. Despite the importance of Australia's natural assets, few protected areas have stand-alone management guidelines to ensure that such values are maintained. Although progress is being made, there are few legislative requirements in Australia for monitoring visitor impacts and currently impacts are rarely adequately monitored (Buckley 2004; Hadwen et al. 2005a; Worboys et al. 2005). Even when there is visitor monitoring, it is 
usually not integrated into overall management evaluation frameworks (McArthur \& Sebastian 1998; Brown et al. 2006). In addition, the capacity of management agencies to develop and implement visitor monitoring is in its infancy and many managers have identified that there are too many reporting systems and different methods for evaluation (Worboys 2007).

Two of the most widely-used, general frameworks for identifying ecological indicators include the PressureState-Response (PSR) model (e.g. Newton \& Kapos 2002) and Noss’s $(1990,1999)$ framework for selecting indicators of biodiversity. The hierarchical framework proposed by Noss (1990) enabled complex ecological systems to be monitored using simplified variables (indicators) that could be aggregated across different scales for evaluation and reporting. In recent years, the PSR model has been modified to accommodate specific monitoring requirements, as well as 'Driving forces' and 'Impacts' as key components to take social, economic and institutional factors into account (e.g. CSD 2001).

Accurate, timely and cost-effective evaluation of ecological integrity depends on using appropriate monitoring programs with suitable indicators (Noss 1990; Niemi \& McDonald 2004). The selection of indicators for visitor monitoring depends on their ability to inform clearly defined objectives (Buckley 2003; Wiersma 2005) and there are a number of key issues that need to be taken into consideration when selecting indicators.

Firstly, it is difficult to select appropriate ecological indicators for diffuse, and difficult to detect, impacts of visitors (Warnken \& Buckley 2000), particularly those occurring across multiple spatio-temporal scales (Buckley 2003). Secondly, impacts should be prioritised prior to selecting indicators (Jennings 2005), as failure to do so may result in unrealistic goals being set that cannot be achieved. Thirdly, indicators are designed to facilitate understanding of ecological condition and trends in condition. Setting condition thresholds around an acceptable range has increasingly been used as an approach to ecosystem management and is useful when dealing with dynamic ecosystems (Biggs \& Rogers 2003). As a result, indicator values may not be static and should be subject to revision and modification based on the best available information.

In addition, often the selection of appropriate indicators is hampered by poor objective setting (Dale \& Beyeler 2001) as well as the failure to recognise the complexity of ecological systems (Yoccoz et al. 2001). Of further concern is the scale at which indicators are selected. It has been suggested that long-term anthropogenic stress, including visitor impact, is best monitored at a community level rather than at the level of a single species (Odum 1985). Furthermore, there is a 
need to focus on the application of functional or ecosystem process indicators, rather than structural (community composition) indicators.

Monitoring programs should be rigorously designed and implemented (Wiersma 2005) to ensure that potential indicators meet an array of pre-selected criteria (Dale \& Beyeler 2001; Buckley 2003; Miller \& Twining-Ward 2005; Wiersma 2005) (Table 4).

Table 4: Summary of criteria for selecting ecological indicators from recreation ecology literature and the frequency of reporting in the literature.

\begin{tabular}{|c|c|}
\hline Criteria & Authors \\
\hline \multicolumn{2}{|l|}{ Essential criteria } \\
\hline Easily measurable, reliable repeated measures, large sampling windows & $1,2,3,4,6,7,8,9,11,12$ \\
\hline Have known responses to natural disturbance and anthropogenic stress, discriminatory & $1,2,3,6,7,9,10,12$ \\
\hline Ecologically significant, credible & $2,3,5,6,11,12$ \\
\hline Low impact to measure & 3 \\
\hline Meaningful for management and other stakeholders (policy relevant) & $3,5,7,10,11$ \\
\hline Directly linked to visitor use and impact & $2,3,13$ \\
\hline \multicolumn{2}{|l|}{ Other criteria } \\
\hline Sensitive to stress on ecosystems & $1,2,6,7,9,13,14$ \\
\hline Predictable stress response (quick response) & $1,3,4,13,14,15$ \\
\hline Anticipatory & 1,6 \\
\hline Predict changes that can be averted by management action, actionable & $1,2,3,7,9,13,14$ \\
\hline Integrative across the full spectrum of spatiotemporal ecological gradients & $1,2,6,7$ \\
\hline Low variability in responses, i.e. precise and accurate measures & $1,3,9,10,12$ \\
\hline Feasible, cost effective & $2,3,4,9,10,11,12,13,14$ \\
\hline Management capacity (ease of training) & $3,13,14$ \\
\hline Builds on available baseline data & $3,9,11$ \\
\hline Ease of identification (fauna and flora indicators) & 4 \\
\hline Public interest, transparent, reflect social and political interests & $4,5,11,15$ \\
\hline Independent of sample size & 6 \\
\hline Addresses management objectives—outcome driven & $5,7,11,12$ \\
\hline Report against as many evaluation components as possible for performance reporting & 7,11 \\
\hline Should report on outputs rather than inputs & 8 \\
\hline Should be descriptive rather than evaluative & 8 \\
\hline
\end{tabular}

Authors: 1) Dale \& Beyeler (2001); 2) Buckley (2003); 3) Belnap (1998); 4) Niemi \& McDonald (2004); 5) McCool \& Stankey (2004); 6) Noss (1990); 7) Moore et al. (2003); 8) Eagles et al. (2002); 9) Rome (1999); 10) Ward et al. (2002); 11) Heinemann et al. (1998); 12) Kurtz et al. (2001), 13) Hadwen et al. (2003) 14) Hadwen et al. (2005a), 15) Hadwen \& Arthington (2003) 
This paper does not develop a specific set of indicators for monitoring ecological condition for all Australian protected areas as appropriate indicators depend on the individual circumstances of each area. Furthermore, guidelines and indicators have been previously developed for Australia (Heinemann et al. 1998; ANZECC 2000). This paper draws from previous recommendations and proposes the use of an integrated framework for developing indicators for visitor monitoring which forms the mainstay of an adaptive monitoring and evaluation strategy. Castley et al. (2008) provided a list of potential indicators categorised on their ability to provide information about vegetation, soil, wildlife, ecological processes, ecological integrity and secondary effects so that relevant indicators can be selected for any given park. We advocate the use of Noss's (1990) diversity hierarchy across various spatial scales as the use of this approach within our integrated framework will focus the manager's attention towards identification of ecological indicators.

The key is matching indicators with explicitly stated objectives and goals for a particular protected area, listing critical issues, and then identifying appropriate measures to collate the data from these indicators. This facilitates an understanding of the linkages between the indicators and visitor use (Reynolds \& Braithwaite 2001). Our framework is designed to incorporate these broader approaches into indicator selection and implementation by adopting an adaptive impact management (Enck et al. 2006) approach to managing visitor use.

\section{Towards an integrated framework for monitoring ecological impacts}

The development of specific frameworks to assist with the management of visitors in protected areas has been a sequential process, with newer frameworks often incorporating aspects of previous frameworks as well as aspects of general ecological indicator frameworks. Earlier frameworks, such as the Recreation Opportunity Spectrum (ROS) and Visitor Impact Management (VIM) that are widely used within Australia (McArthur \& Sebastian 1998; Brown et al. 2006), are potentially able to identify impacts at an early stage but have two main limitations. Firstly, they seldom link an impact with its causes, and secondly, they rarely go beyond identifying site-specific impacts (Nilsen \& Tayler 1998). More recent frameworks that use Thresholds of Potential Concern (TPC) and Decision Support Systems/Tourism Natural Asset Classification (DSS/TNAC) take into account the dynamic nature of the environment and allow managers to assess changes along environmental gradients rather than defining specific end points (Biggs \& Rogers 2003; Hughey et al. 2004). 
Recent frameworks (e.g. DSS/TNAC) build on the complex adaptive systems approach (Miller \& Twining-Ward 2005) while also drawing from research into the resilience of ecosystems (Walker et al. 2002). They address sustainable tourism through understanding the inherent instability in ecological systems but also identify important components within these systems that are subject to continual change. They also stress the need to select appropriate indicators at a range of spatial and temporal levels (Ward et al. 2002; Hughey et al. 2004; Hadwen et al. 2005a). Castley et al. (2008) reviewed the application of these frameworks in developing the current integrated adaptive approach.

In addition to monitoring impacts, protected area agencies are increasingly required to evaluate and report on their management effectiveness and performance (Hockings 2003; Tonge et al. 2005; Worboys et al. 2005; Hockings et al. 2006), and management frameworks facilitate the linkage of planning, monitoring and evaluation (Hockings 1998). Broad-scale assessment of the condition of the environment and the severity of major threats is one component of State of the Parks and World Heritage Area reporting (Environment Australia 2003) but this appears to be lacking at the individual park level (Hockings et al. 2004, 2006).

Our framework integrates visitor impact monitoring and evaluation within the protected area management cycle to overcome institutional limitations (e.g. capacity, finances, reporting) and provides feedback that enables managers to improve management. The integrated framework is linked to the expanded-WCPA management effectiveness evaluation framework, based on evaluation subjects (Hockings et al. 2004; Worboys 2007) and uses, as far as possible, existing management processes for focusing monitoring effort and selecting ecological indicators that are applicable at various reporting levels (e.g. sites, habitat, park, organisation).

\section{A new integrated framework for monitoring}

Although monitoring and assessment should be conducted of natural assets used or affected by visitors, agencies commonly have insufficient funding to support such full and comprehensive evaluation. Therefore, our framework recommends prioritising visitor impact monitoring based on: (1) the importance, value or significance of assets (see Ward et al. 2002; Hughey et al. 2004); (2) the vulnerability of assets; and (3) the pressure or threat from visitor use.

Natural assets could be a type of habitat, ecosystem, or physical landscape. They can occur in one or multiple locations within a protected area and can range in size from small, discrete locations 
(e.g. visitor lookouts, picnic areas, hardened campsites) to extensive areas (e.g. sand dune ecosystems used for camping by off-road vehicle users which can extend for many kilometres). Assets also can be components of the physical environment (e.g. a cave, mountain-top, snow bank, hot spring, waterfall), flora and vegetation (e.g. littoral rainforest, short alpine herbfields) or fauna (e.g. terrestrial or aquatic mammals, birds, reptiles, insects, glow worms).

In general, ecological concepts for determining the importance and value of natural phenomena include knowledge of their rarity, diversity and habitat condition. The vulnerability of natural phenomena is also determined using ecological concepts such as resistance or resilience. Finally, assets used by visitors should be prioritised based on the severity of threat from visitor use. This is achieved through understanding and identifying the types and potential impacts of activities and infrastructure at assets.

The preceding review provided the basis for the development of our integrated framework of six steps: (1) identifying management objectives and relevant evaluation subjects; (2) classifying natural assets and threats to those assets; (3) prioritising sites for visitor monitoring; (4) selecting ecological indicators of visitor impacts; (5) developing monitoring programs for indicators; and (6) using results to improve future management (adaptive management) (Figure 1). To illustrate how the framework might be applied, we provide guidelines for each step before illustrating this application using an example (Figure 2).

Step 1. Determine management objectives for the park and evaluation subject/s relevant to visitor impacts on natural values

It is necessary to identify management objectives relating to the conservation and protection of natural assets and visitor use before implementing this framework. Objectives for the management of park types are usually set out in relevant state and Commonwealth legislation, as well as in plans of management and performance reporting documents. The primary management objective of many protected areas is to conserve representative samples of flora, fauna and scenery, and to conserve cultural heritage, with other areas reserved primarily for recreation and open space values.

After establishing management objectives for a protected area, it is necessary to determine the relevant evaluation subject/s for assessing visitor use. Examples of these can be found in the expanded-WCPA evaluation framework (Castley et al. 2008; Worboys 2007). The core evaluation subject with primary relevance for visitor use impacts is 'severity of threat from visitor 


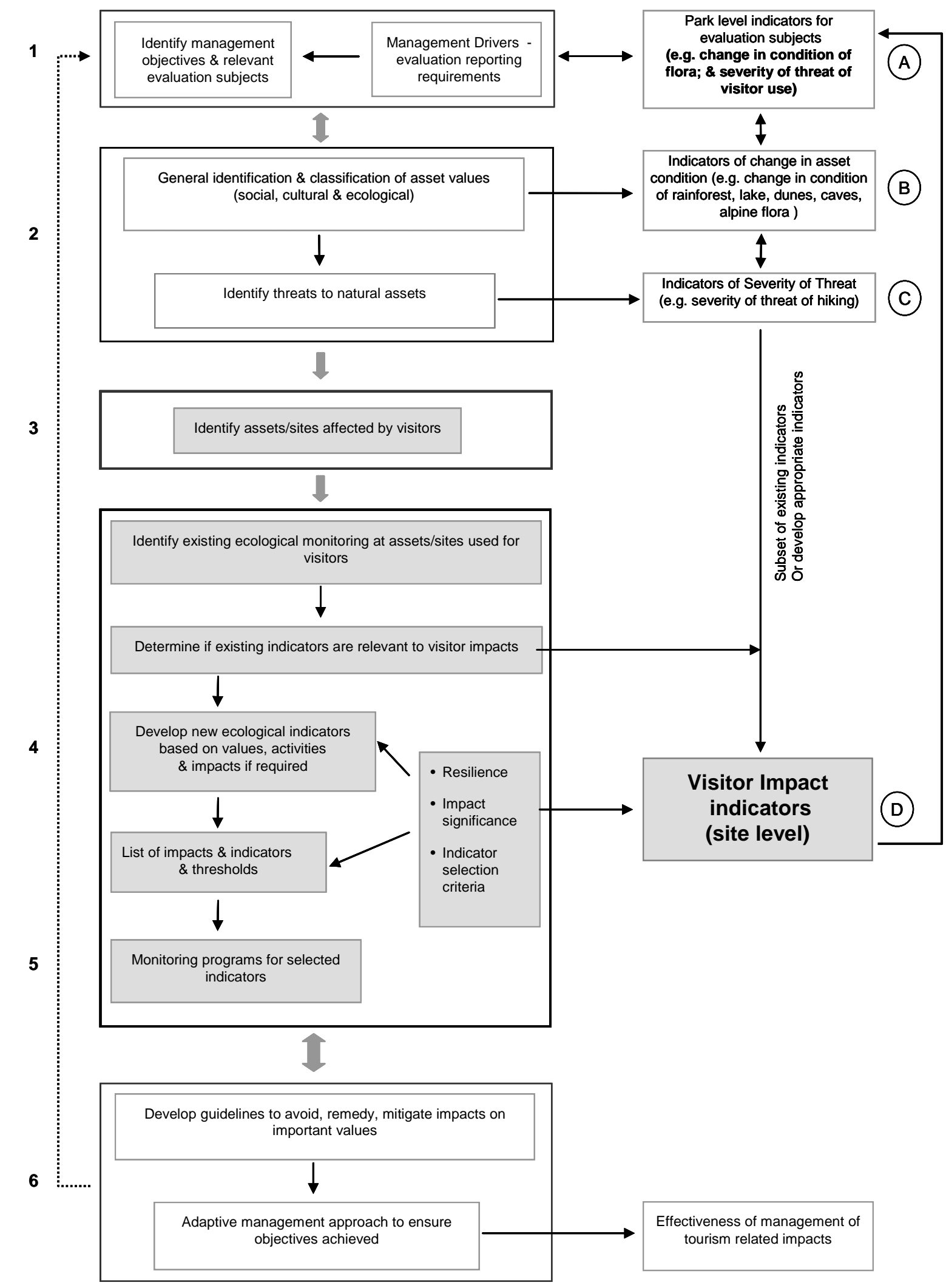

Figure 1: Integrated framework for developing ecological indicators of visitor impacts in protected areas. Numbers 1-6 represent key steps in the framework while letters A-D reflect how indicators can be used in a performance evaluation hierarchy. 
use'. Other relevant core evaluation subjects are baseline values of flora, fauna, ecosystem/habitat/land types, and change in condition of flora, fauna, habitat, geological feature, or landscape type. Additional evaluation subjects are the severity of threat from weeds, pest animals and fire regimes.

\section{Step 2. Prioritise natural assets and threats to assets}

To focus monitoring effort, natural assets are prioritised based on three characteristics: (1) the importance and value of the assets; (2) the vulnerability of the assets; and (3) the threats to the assets from visitor use. Methodologies for prioritising the value of natural assets are often documented by relevant protected area management organisations and other agencies responsible for State of the Environment reporting. Toolkits for scoring biodiversity values are also available (Oliver 2004). Prioritising of natural assets may already be established for some protected areas. However, there is growing recognition that this is generally not the case for freshwater ecosystems (Hadwen et al. 2005b; Abell et al. 2006). Based on existing assessments, it would be useful, as a minimum, to categorise the value of flora, fauna or physical feature assets as high, moderate or low.

Vulnerability may have been established for many assets in some protected areas. If not, classification based upon the fragility of the asset as resistant or resilient, moderate or fragile can be established for the asset type and class. Threats to the natural values of prioritised assets are then identified. For example, removal of habitat for provision of infrastructure, spread of exotic species, altered water and fire regimes, and inappropriate visitor use have been identified as processes impacting natural values of protected areas worldwide.

\section{Step 3. Prioritise assets used by visitors for monitoring}

The natural assets used and impacted by visitors need to be identified. These assets will be a subset of all assets identified in Step 2, and are used to prioritise the assets for monitoring. The prioritisation will be based on the importance and vulnerability of the assets, the types of visitor activities, and the severity of impacts. Information on visitor activities and impacts at natural assets may occur already in plans of management, annual plans, World Heritage Area reporting, and management agency GIS mapping of park assets, including Recreational Opportunity Spectrum (ROS) mapping. However, not all visitor use impacts have been incorporated into park management plans. A list of activities and their associated ecological impacts is provided by Castley et al. (2008). 
For Steps 1-3, if there are no existing processes for prioritising natural assets and identifying threats for protected areas, an approach based on the DSS/TNAC framework recently developed for monitoring and evaluating the sustainable tourism use of natural assets in New Zealand is suggested (Ward et al. 2002; Hughey et al. 2004).

Step 4. Select ecological indicators of severity of the threat from visitor use for priority sites Indicators are selected based on the particular characteristics of the asset as well as the type of visitor activity. For assets identified in Step 3, appropriate visitor impact monitoring may be occurring already. If not, relevant indicators of change in the condition of the asset should be identified. In some instances, appropriate indicators may not have been sufficiently field-tested to facilitate their immediate implementation. Causal links between some recreation activities and impacts often have been well established by research ecologists and do not need to be experimentally established in specific monitoring programs (e.g. recreational trampling and camping impacts, see Castley et al. 2008). The assumption is that, if adverse changes in condition are detected, then those changes are the result of visitor use.

Step 5. Develop monitoring programs for indicators

Assessing change in the condition of assets as a result of visitor use is achieved by implementing monitoring at a discrete natural asset or at a site representing the asset being assessed. This step is likely to require the involvement of recreation ecologists. For example, guidelines have been developed recently for assessing tracks in protected areas (Hill \& Pickering 2009).

\section{Step 6. Develop guidelines to mitigate impacts}

Information on how to mitigate the impacts of visitors can be found in technical and management reports, as well as in recent reviews of visitor impacts (Sun \& Walsh 1998; Newsome et al. 2002a; Buckley 2003, 2004; Hadwen et al. 2005b). For example, strategies to limit the introduction and spread of weeds should take into account the role of visitor infrastructure and activities in this process.

An adaptive management approach is recommended to allow managers to assess changes in natural ecosystems and to respond accordingly. This enables monitoring to assess natural ecosystem fluxes so that managers can respond by revising impact monitoring in a strategic, rather than reactive, manner (Salafsky et al. 2002; Biggs \& Rogers 2003). 


\section{Indicator hierarchy}

At various steps in the integrated framework, indicators can be derived to address visitor impacts at variable scales (A-D in Figures 1 and 2). Indicators selected through the consideration of both visitor use and asset characteristics enable monitoring to be implemented at a single site or multiple sites. The single site-based approach is commonly used given that visitor impacts tend to be localised and severe. Here, it is important that agencies monitor changes in condition against established benchmarks (Buckley 2003). Indicators are able to inform management decisionmaking through the provision of evaluation information which can be applied across an evaluation hierarchy (e.g. site, asset, park). Site-specific information can be used to inform local actions (e.g. weed control, track rehabilitation) while aggregation of information is possible at higher organisational levels where such information is typically less specific, such as in park performance reporting (Worboys 2007). However, it is important to note that aggregation of data and information at higher levels could understate the level of visitor impacts, and some standardisation may be required to facilitate comparative evaluation (Buckley 2003).

\section{Applying the new, integrated framework: a hypothetical example}

In this example, we review each step of our framework and demonstrate its application within an appropriate visitor impact assessment context (Figure 2).

Park level indicators for
'change in condition of flora'
$\begin{aligned} & \text { Indicators for change in condition of } \\ & \text { specific asset (e.g. rainforest, dunes, } \\ & \text { caves, alpine flora) }\end{aligned}$
$\begin{aligned} & \text { (C) Indicators of severity of specific } \\ & \text { threats (e.g. exotic plants, visitor } \\ & \text { use) }\end{aligned}$
$\begin{aligned} & \text { Site level indicators of } \\ & \text { 'severity of threat of visitor } \\ & \text { use' }\end{aligned}$
Feral animals
Control of weeds; wash down for shoes/vehicles,
revegetation of road verges with natives
Reduced cover of weeds, root rot in park has not
spread, no soil erosion from track or lookout

Figure 2: Example of use of the integrated framework (Fig. 1) for the evaluation subject 'change in condition of flora' for a given park. 
Step 1. The evaluation subject 'severity of threat from visitor use' was selected in the example protected area. Other core evaluation subjects relevant for evaluation could be change in condition of flora or habitat.

Step 2. In the example, seven natural assets were identified and prioritised based on their value and vulnerability. These assets could include sensitive habitats and species (e.g. wetlands, alpine communities, viewpoints, threatened communities, walking tracks, native wildlife). Five threats were associated with these natural assets. At two natural assets, visitor use (inappropriate visitor loads and activities) was identified as a threat.

Step 3. Assets 5 and 6 are used for camping and sightseeing, and asset 6 is also a lookout. Impacts from these activities have been identified and include loss of vegetation, soil erosion, soil compaction, wildlife disturbance, as well as the introduction of weeds and fungal pathogens. Based on the value and vulnerability of the assets and the severity of visitor use, both assets were identified as priorities for monitoring.

Step 4. Indicators were selected to assess change in condition from camping and sightseeing at assets used by visitors. Ecological indicators could include change in vegetation structure and composition at asset 5, including the extent of weeds (baseline values initially), and then spread of weeds over time. Soil erosion, bare ground (baseline), and increase in bare ground and soil erosion could be monitored at asset 6 .

Step 5. Long-term monitoring systems, for example, ongoing assessment of weed community changes, visitor numbers, are established if not already in place for the identified threats to the two assets.

Step 6. An experimental approach to monitoring is adopted by management agencies to assess the effectiveness of the management actions, with the results being fed back into the decision-making process to determine whether the management objectives have been met for the particular assets.

\section{Implementation of the framework and future directions}

This framework provides protected area agencies with a method for focusing monitoring effort and selecting ecological indicators, which, if monitored appropriately, will provide information 
on the change in condition of ecosystems at sites. This will enable managers to develop proactive programs for managing ecosystems and their use by visitors. However, focusing monitoring effort and developing indicators are just the first stages.

Effective monitoring programs are also required. Protected area managers need information on how to develop and implement effective visitor monitoring (Hadwen et al. 2005b). Hill and Pickering (2009) illustrated the importance of this approach by showing how specific indicators of visitor impacts can be developed within an integrated framework to assess walking track impacts in protected areas, as tracks are among the most common infrastructure provided by protected area managers.

An adaptive approach to visitor management is not yet common in protected areas worldwide. Many management strategies were designed to achieve sustainable visitor use but do not have a sound basis in science, instead depending on the intuition and personal judgments of managers (Monz \& Leung 2006). This is no longer adequate. Visitor use continues to impact the natural environment in protected areas worldwide, and it is vital that visitor management is based on systematic information. This includes information on how many visitors there are, where they go, and what they do. This framework provides the basis for such a strategic adaptive approach.

Another key feature of our integrated framework is that the final set of indicators (if monitored appropriately) should facilitate management intervention to take place. This will be the key to successful monitoring and reporting of ecological impacts. The importance of these feedback loops in the framework is critical to its adaptive capacity to evolve with changing circumstances (within ecological, social, political, economic climates). Managers therefore need to focus, not only on the nature and consequences of any environmental or ecological change, but also on the resultant management implications (Sheil et al. 2004). Furthermore, interpreting the indicator results requires sound defensible linkages between the indicators and the ecological system component that they represent (Kurtz et al. 2001).

Another anticipated benefit of this particular framework is its generic versatility in performance evaluation. The assessment of visitor use is just one component of overall management performance evaluation. The framework is based on assessing subjects identified in the expanded WCPA protected area management evaluation framework (Worboys 2007). It has the potential to identify indicators in other sectors of protected area management due to its linkage of 
environmental assets with current and future threats. Therefore, it can readily feed into wider performance reporting frameworks at all levels of management.

Finally, agencies are still developing their capacity to undertake visitor monitoring, and this will be enhanced by greater communication between researchers and managers. It is suggested that both groups should take greater responsibility for identifying the impacts of visitors by monitoring impacts in parks (Cole 2006). This framework provides an avenue to reach a common understanding of potential impacts.

The remaining challenge is whether the suite of indicators that are identified can be effectively implemented using the existing capacity within protected areas. Buckley (2003) argued strongly that, in order for effective monitoring of ecological impacts to be completed, managers will have to employ or subcontract external ecologists. The recommendations of ecologists will be implemented by management staff but collaborative involvement in the monitoring process is warranted and encouraged to make these processes amenable to all stakeholders (Miller \& Twining-Ward 2005). The entire process is also likely to be costly and to require contributions of time, expertise and new research effort. Nevertheless, as Wiersma (2005) pointed out, such investments in a rigorous process will be offset by the longer-term rewards of improved management effectiveness.

\section{Acknowledgments}

The authors thank all the researchers and park agency staff involved in this project. In particular, we thank Karen Higginbottom, Glenn Sanecki and Ralf Buckley for their constructive comments. The Sustainable Tourism Cooperative Research Centre, established and supported under the Australian Government’s Cooperative Research Centres Program, funded this research.

\section{References}

Abell, R., Allan, J. D. \& Lehner, B. 2006, Unlocking the potential of protected areas for freshwaters. Biological Conservation, vol. 134, pp. 48-63.

ANZECC (Australian and New Zealand Environment and Conservation Council State of the Environment Reporting Task Force) 2000, Core Environmental Indicators for Reporting on the State of the Environment. Environment Australia, Canberra. 
Belnap, J. 1998, Environmental auditing, choosing indicators of natural resource condition: A case study in Arches National Park, Utah, USA. Environmental Management, vol. 22, pp. 635-642.

Biggs, H.C. \& Rogers, K.H. 2003, An adaptive system to link science, monitoring, and management in practice. In: J.T. Du Toit, K.H. Rogers \& H.C. Biggs (Eds) The Kruger Experience: Ecology and Management of Savanna Heterogeneity. Island Press, Washington. pp. 59-80.

Brown, G., Koth, B., Kreag, G. \& Weber, D. 2006, Managing Australia's Protected Areas: a Review of Visitor Management Models Frameworks and Processes. Sustainable Tourism CRC Griffith University, Gold Coast. 98pp.

Buckley, R. 2003, Ecological indicators of tourism impacts in parks. Journal of Ecotourism, vol. 2, 54-66.

Buckley, R. 2004, (Ed.) Environmental Impacts of Tourism CABI Publishing, Oxford.

Buckley, R. 2008, Off-road vehicles in protected areas. In: Cater, C. (ed.) High Impacts Activities in Parks: Best Management Practice and Future Research. CRC for Sustainable Tourism, Griffith University, Gold Coast, pp. 22-25.

Carey, C. Dudley, N. \& Stolton, S. 2000, Squandering Paradise? The importance and vulnerability of the world's protected areas. World Wide Fund for Nature, Gland, Switzerland.

Castley, J.G. Hill, W. Pickering, C. Hadwen, W \& Worboys, G. 2008, An integrated framework for developing ecological indicators of visitor use in protected areas. CRC for Sustainable Tourism Technical Report, Griffith University, Gold Coast. 54pp.

Cater, C. \& Hales, R. 2008, Rock climbing in protected areas. In: Cater, C. (ed.) High Impacts Activities in Parks: Best Management Practice and Future Research. CRC for Sustainable Tourism, Griffith University, Gold Coast, pp. 26-35. 
Chiu, L. \& Kriwoken, L. 2003. Managing recreational mountain biking in Wellington Park, Tasmania, Australia. Annals of Leisure Research vol 6, pp. 339-361.

Choi, H.C. \& Sirakaya, E. 2006, Sustainability indicators for managing community tourism. Tourism Management, vol. 27, pp. 1274-1289.

Cole, D.N. 2004, Impacts of hiking and camping on soils and vegetation: a review. In: Buckley, R. (ed.) Environmental Impacts of Ecotourism. CABI Publishing, New York, pp.41-60.

Cole, D.N. 2006, Visitor and recreation impact monitoring: Is it lost in the gulf between science and management? The George Wright Forum, vol. 23, pp. 11-16.

CSD (Commission on Sustainable Development) 2001, Indicators of Sustainable Development: Guidelines and Methodologies. Commission on Sustainable Development, New York.

Dale, V.H. \& Beyeler, S.C. 2001, Challenges in the development and use of ecological indicators. Ecological Indicators, vol. 1, pp. 3-10.

DEH (Department of Environment and Heritage) 2006, CAPAD, the Collaborative Australian Protected Areas Database, DEH, Canberra, viewed 11 November 2009, http://www.environment.gov.au/parks/nrs/science/capad/2006/index.html.

Eagles, P.F.J. McCool, S.F. \& Haynes, C.D.A. 2002, Sustainable Tourism in Protected Areas: Guidelines for Planning and Management. WCPA Gland, Switzerland.

Enck, J.W. Decker, D.J. Riley, S.J. Organ, J.F. Carpenter, L.H. \& Siemer, W.F. 2006, Integrating ecological and human dimensions in adaptive management of wildlife related impacts. Wildlife Society Bulletin, vol. 34, issue 3, pp. 698-705.

Environment Australia 1996, Australia State of the Environment 1996. State of the Environment Advisory Council, Department of the Environment Sport and Territories, CSIRO Publishing, Melbourne.

Environment Australia (EA) 2003, ‘World Heritage periodic reporting, Asia Pacific region, 
2003', Australian contribution to the Regional Synthesis Report, Section I, EA, Canberra, viewed 10 November 2009, http://whc.unesco.org/archive/periodicreporting/apa/cycle01/section1/au.pdf.

Goeft, U. \& Alder, J. 2001, Sustainable mountain biking: a case study from the southwest of Western Australia. Journal of Sustainable Tourism, vol. 9, pp. 193-211.

Green, R. \& Higginbottom, K. 2001, Negative effects of wildlife tourism on wildlife. Wildlife Tourism Research Report Series, No. 5. CRC for Sustainable Tourism. Griffith University, Gold Coast. 205pp.

Hadwen W. L. \& Arthington A. H. 2003, The significance and management implications of perched dune lakes as swimming and recreation sites on Fraser Island, Australia. The Journal of Tourism Studies, vol. 14, pp. 35-44.

Hadwen W. L., Arthington A. H., Boon P. I., Lepesteur M. \& McComb A. J. 2005b, Rivers, streams, lakes and estuaries: hot spots for cool recreation and tourism in Australia. CRC for Sustainable Tourism - CRCST Press, Gold Coast.

Hadwen W. L., Arthington A. H. \& Mosisch T. D. 2003, The impact of tourism on dune lakes on Fraser Island, Australia. Lakes and Reservoirs: Research and Management, vol. 8, pp. 15-26.

Hadwen W. L. \& Bunn S. E. 2004, Tourists increase the contribution of autochthonous carbon to littoral zone food webs in oligotrophic dune lakes. Marine and Freshwater Research, vol. 55, pp. 701-708.

Hadwen W. L., Bunn S. E., Arthington A. H. \& Mosisch T. D. 2005a, Within-lake detection of the effects of tourist activities in the littoral zone of oligotrophic dune lakes. Aquatic Ecosystem Health and Management, vol. 8, pp. 159-173.

Hall, C.M. \& McArthur, S. 1993, Heritage management in New Zealand and Australia: visitor management, interpretation and marketing. Oxford University Press, Auckland.

Heinemann, D., Higgins, J., McAlpine, G., Raison, J., Ryan, S. \& Saunders, D. 1998, A Guidebook to Environmental Indicators. CSIRO, Canberra. 
Hill, W. \& Pickering C.M. 2009, Evaluation of impacts and methods for the assessment of walking tracks in protected areas. CRC for Sustainable Tourism Technical Report, Griffith University, 33pp.

Hockings M 1998. Evaluating management of protected Areas: integrating planning and evaluation. Environmental Management, vol. 22, pp. 337-346.

Hockings, M. 2003, Systems for assessing the effectiveness of management in protected areas. Bioscience, vol. 53, pp. 823-832.

Hockings, M. Stolton, S \& Dudley, N. 2004. Management Effectiveness - assessing management of protected areas. Journal of Environmental Policy and Planning, vol. 6(2), pp. 157-174.

Hockings, M. Stolton, S. Leverington, F. Dudley, N. \& Corrau, J. 2006, Evaluating Effectiveness: a framework for Assessing Management Effectiveness of Protected Areas 2nd edition. International Union for the Conservation of Nature World Commission on Protected Areas, Gland, Switzerland.

Hughey, K.F.D. Ward, J.C. Crawford, K.A. McConnell, L. Phillips, J.G. \& Washbourne, R. 2004, A classification framework and management approach for the sustainable use of natural assets used for tourism. International Journal of Tourism Research, vol. 6, pp. 349-363.

Jennings, S. 2005, Indicators to support an ecosystem approach to fisheries. Fish and Fisheries, vol. 6, pp. 212-232.

Kurtz, J.C. Jackson, L.E. \& Fisher, W.S. 2001, Strategies for evaluating indicators based on guidelines from the Environmental Protection Agency’s Office of Research and Development. Ecological Indicators, vol. 1, pp. 49-60.

Landsberg, J. Logan, B. \& Shorthouse, D. 2001, Horse riding in urban conservation areas: reviewing scientific evidence to guide management. Ecological Management and Restoration vol. 2, pp. 36-46. 
Leung, Y-F. \& Marion, J.L. 2000, Recreation impacts and management in wilderness: a state-ofknowledge review. In: D.N. Cole, S.F. McCool, W.T. Borrie, \& J. O’Loughlin (Eds.) Wilderness Science in a Time of Change - Volume 5: Wilderness Ecosystems, Threats, and Management. Proceedings RMRS-P-15-Vol-5. U.S. Department of Agriculture, Forest Service, Rocky Mountain Research Station. Bozeman. pp. 23-48.

Locke, H. \& Dearden, P. 2005, Rethinking the protected area categories and the new paradigm. Environmental Conservation, vol. 32, issue 1, pp. 1-10.

Lonsdale, W.M. \& Lane, A.M. 1994, Tourist vehicles as vectors of weed seeds in Kakadu National Park, northern Australia. Biological Conservation, vol. 69, pp. 277-283.

Manning, T. 1999, Indicators of tourism sustainability. Tourism Management, vol. 20, pp. $179-181$.

Margules, C.R. \& Pressey, R.L. 2000, Systematic conservation planning. Nature, vol. 405, pp. 243-253.

McArthur, S. \& Sebastian, I. 1998, Implementation of impact management models - who's doing what across Australia. In: Proceedings of the Ecotourism Association of Australia. 1998 National Conference, “Developing Tourism into the Millennium”. Ecotourism Association of Australia, Brisbane. pp 58-67.

McCool, S.F. \& Stankey, G.H. 2004, Indicators of sustainability: challenges and opportunities at the interface of science and policy. Environmental Management, vol.33, pp. 294-305.

Miller, G. \& Twining-Ward, L. 2005, Monitoring for a Sustainable Tourism Transition: the Challenge of Developing and Using Indicators. CABI Publishing, Oxford.

Monz, C. \& Leung, Y. 2006, Meaningful measures: developing indicators of visitor impact in the National Park Service inventory and monitoring program. The George Wright Forum, vol. 23, pp. $17-27$. 
Moore, S.A. Smith, A.J. \& Newsome, D.N. 2003, Environmental performance reporting for natural area tourism: contributions by visitor impact management frameworks and their indicators. Journal of Sustainable Tourism, vol. 11, pp. 348-375.

Mosisch, T.D. \& Arthington, A.H. 2004, Impacts of recreational power-boating on freshwater ecosystems. In: Buckley, R. (ed.) Environmental Impacts of Ecotourism. CABI Publishing, New York, pp. 125-154.

Newsome, D. Cole, D.N. \& Marion, J.L. 2004, Environmental impacts associated with recreational horse-riding. In: R. Buckley (Ed.) Environmental Impacts of Tourism. CABI Publishing, Oxford. pp. 61-82.

Newsome, D., Moore, S.A. \& Dowling, R.K. 2002a, Natural Area Tourism: Ecology, Impacts and Management. Channel View Publications, Sydney.

Newsome, D. Phillips, N. Milewskii, A. \& Annear, R. 2002b, Effects of horse riding on national parks and other natural ecosystems in Australia: implications for management. Journal of Ecotourism, vol. 1, pp. 52-74.

Newsome, D. Smith, A. \& Moore, S.A. 2008. Horse Riding in Protected Areas: A Critical Review and Implications for Research and Management. Current Issues in Tourism, vol 11, pp. 144-166.

Newton, A.C. \& Kapos, V. 2002, Biodiversity indicators in national forest inventories. Unasylva, vol. 53, pp. 546-64.

Niemi, G.J. \& McDonald, M.E. 2004, Application of ecological indicators. Annual Review of Ecology, Evolution and Systematics, vol. 35, pp. 89-111.

Nilsen, P. \& Tayler, G. 1998, A comparative analysis of protected area planning and management frameworks. In: S.F. McCool, D.N. Cole (Eds) Proceedings - Limits of Acceptable Change and Related Planning Processes: Progress and Future Directions. Gen. Tech. Rep. INT-GTR-371. U.S. Department of Agriculture, Forest Service, Rocky Mountain Research Station. Bozeman. pp. 49-57. 
Noss, R.F. 1990, Indicators for monitoring biodiversity: a hierarchical approach. Conservation Biology, vol. 4, pp.: 355-364.

Noss, R.F. 1999, Assessing and monitoring forest biodiversity: a suggested framework and indicators. Forest Ecology and Management, vol. 115, pp. 135-146.

Odum, E.P. 1985, Trends expected in stressed ecosystems. Bioscience, vol. 35, pp. 419-422.

Oliver, I. 2004, A framework and toolkit for scoring the biodiversity value of habitat, and the biodiversity benefits of land use change. Ecological Management and Restoration, vol. 5, pp. 75-77.

Orfanidis, S. Panayotidis, P. \& Stamatis, N. 2003, An insight to the ecological evaluation index (EEI). Ecological Indicators, vol. 3, pp. 27-33.

Pickering, C.M. \& Hill, W. 2003, Ecological change as a result of winter tourism: snow manipulation in the Australian Alps. In: Buckley, R. Pickering, C.M. \& Weaver, D. (eds.). Nature-based Tourism, Environment and Land Management. CABI Publishing, New York, pp. 137-149.

Reynolds, P.C. \& Braithwaite, D. 2001, Towards a conceptual framework for wildlife tourism. Tourism Management, vol. 22, pp. 31-42.

Rome, A. 1999, Ecotourism Impact Monitoring: a Review of Methodologies and Recommendations for Developing Monitoring Programs in Latin America. Ecotourism Technical Report Series No. 1 The Nature Conservancy, Washington.

Salafsky, N. Margoluis, R. Redford, K.H. \& Robinson, J.G. 2002, Improving the practice of conservation: a conceptual framework and research agenda for conservation science.

Conservation Biology, vol. 16, pp. 1469-1479. 
Sheil, D. Nasi, R. \& Johnson, B. 2004, Ecological criteria and indicators for tropical forest landscapes: challenges in the search for progress. Ecology and Society, vol. 9, issue 1, article 7 [Online] URL http://www.ecologyandsociety.org/vol9/iss1/art7

Smith, A.J. \& Newsome, D. 2008. Horseriding in protected areas. In: Cater, C. (ed.) High Impacts Activities in Parks: Best Management Practice and Future Research. CRC for Sustainable Tourism, Griffith University, Gold Coast, pp. 10-21.

Sun, D., Walsh, D. 1998, Review of studies on environmental impacts of recreation and tourism in Australia. Journal of Environmental Management, vol. 53, pp. 323-338.

Tonge, J., Moore, S.A., Hockings, M., Worboys, G. \& Bridle, K. 2004, Developing Indicators for the Sustainable Management of Visitor use of Protected Areas in Australia - a scoping report. CRC for Sustainable Tourism, Griffith University.

Turton, S.M. 2005, Managing environmental impacts of recreation and tourism in rainforests of the wet tropics of Queensland World Heritage Area. Geographical Research, vol. 43, pp. 140151.

UNEP-WCMC (United Nations Environment Programme - World Conservation Monitoring Centre) 2003, State of the World's Protected Areas (Draft). United Nations, Cambridge. URL, http://sea.unep-wcmc.org/wdbpa/sowpr

Walker, B. Carpenter, S. Anderies, J. Abel, N. Cumming, G. Janssen, M. Lebel, L. Norberg, J. Peterson, G.D. \& Pritchard, R. 2002, Resilience management in social-ecological systems: a working hypothesis for a participatory approach. Conservation Ecology, vol. 6, issue 1, article 14. URL:http://www.consecol.org/vol6/iss1/art14

Ward, J. Hughey, K., \& Ulrich, S. 2002, A framework for managing the biophysical effects of tourism on the natural environment in New Zealand. Journal of Sustainable Tourism, vol. 10, pp. 239-259.

Warnken, J. \& Buckley, R. 2000, Monitoring diffuse impacts: Australian tourism developments. Environmental Management, vol. 25, pp. 453-461. 
Warnken, J. \& Byrnes, T. 2004, Impacts of tour boats in marine environments. In: Buckley, R. (ed.) Environmental Impacts of Ecotourism. CABI Publishing, New York, pp. 99-124.

Wiersma, Y.F. 2005, Environmental benchmarks vs. ecological benchmarks for assessment and monitoring in Canada: Is there a difference? Environmental Monitoring and Assessment, vol. 100, pp. 1-9.

Wilson, R.F. Turton, S.M. Bentrupperbaumer, J.M. \& Reser, J.P. 2004, Visitor Monitoring System for the Wet Tropics World Heritage Area, Volume 1: Procedural Manual. Wet Tropics Management Authority and Rainforest CRC, Cairns.

Worboys, G.L., Lockwood, M., \& De Lacy, T. 2005, Protected Area Management Principles and Practice 2nd edition. Oxford University Press, Melbourne.

Worboys, G.L. 2007, Evaluation subjects and methods required for managing protected areas. PhD Thesis, Griffith University, Gold Coast. 529pp.

Yoccoz, N.G. Nichols, J.D., \& Boulinier, T. 2001, Monitoring of biological diversity in space and time. Trends in Ecology and Evolution, vol. 16, pp. 446-453. 